\title{
PERSEPSI MAHASISWA UNIVERSITAS NEGERI MEDAN MENGENAI UMUR AWAL PERNIKAHAN REMAJA PEREMPUAN KURANG DARI 20 TAHUN
}

\author{
Mona Adria Wirda, Desi Permata Sari, Ira Azzahra, Kartika Anisya, Simon P. B \\ Situmorang, Wirda Ashma Fadhillah \\ Jurusan Pendidikan Geografi, Fakultas Ilmu Sosial \\ Universitas Negeri Medan \\ Deli Serdang, Sumatera Utara 20221, Indonesia \\ Email: depesari25@gmail.com
}

\begin{abstract}
Abstrak
Pernikahan yang terjadi pada usia muda dikalangan mahasiswa merupakan salah satu kejadian yang jarang ditemukan. Pernikahan adalah upacara pengikatan janji nikah yang dirayakan atau dilaksanakan oleh dua orang dengan maksud meresmikan ikatan perkawinan secara norma agama, norma hukum, dan norma sosial. Penelitian ini bertujuan untuk mengetahui persepsi mahasiswa Universitas Negeri Medan mengenai umur awal pernikahan remaja perempuan kurang dari 20 tahun. Penelitian ini berlokasi di Universitas Negeri Medan. penelitian ini menggunakan instrumen kuesioner yang datanya dianalisis menggunakan pendekatan deskriptif kualitatif. Sampel yang digunakan sebanyak 77 mahasiswa. Data yang diperoleh dari hasil penelitian melalui kuesioner adalah sebesar 5,19\% mahasiswa sangat setuju dengan peraturan pembatasan usia menikah bagi perempuan di atas 20 tahun, setuju dengan persentase sebesar 38,96\%.Umur yang ideal untuk menikah yaitu berkisar antara umur 21 tahun bagi perempuan dan 25 tahun bagi laki-laki.
\end{abstract}

\section{Kata Kunci: Pendapat Mahasiswa, Pernikahan, Usia Awal Menikah Perempuan}

\section{PENDAHULUAN}

Pada fase atau tahap usia remaja sering dianggap sebagai tahap yang paling tidak stabil dalam perkembangan manusia, GS. Hall (1993) mengatakan tidak ada definisi serta batasan usia yang baku untuk kelompok usia yang biasa disebut remaja, namun secara umum, remaja biasanya dianggap sebagai kelompok usia antara anak-anak dan dewasa, kurang lebih antara usia 12 dan 20 tahun. Lebih lanjut, Atkinson, R.L., Atkinson, R.C., Hilgard, E.R. (1999) menjelaskan bahwa setidaknya ada tiga aspek penting yang menandai masa remaja: 1) Terjadinya perubahan fisik (berkembangnya hormon dan organ-organ seksual), 2) Adanya pemantapan identitas diri, dan 3) Adanya persiapan menghadapi tugas dan tanggung jawab sebagai manusia yang mandiri.

Hasil dari beberapa penelitian mengemukakan bahwa salah satu penyebab pernikahan usia muda adalah akibat dari sangat buruk ataupun sangat tidak berkualitas tingkat pendidikan di Indonesia (Rafidah dkk, 2009; Nurwati, 2003; Fatmawati, 2009). Namun saat ini fenomena menikah muda ternyata tidak hanya terjadi di kalangan mereka yang berpendidikan rendah. Pernikahan di kalangan mahasiswa misalnya, kerap dijumpai di berbagai perguruan tinggi di Indonesia.

Tidak ada batasan usia yang konkret untuk menikah jika dilihat dari perspektif agama. Batasan hanya diberikan berdasarkan kualitas yang harus dipenuhi oleh mereka sebagaimana dalam QS : AnNisa' ayat 6 yang artinya :

"Dan ujilah anak yatim itu sampai mereka sampai mereka cukup umur untuk kawin, kemudian jika menurut pendapatmu mereka telah cerdas (pandai memelihara harta), maka serahkanlah kepada mereka harta-hartanya."

Yang dimaksud dengan cukup umur untuk menikah dalam ayat di atas adalah setelah timbul keinginan untuk berumah tangga, dan siap menjadi suami dan memimpin keluarga. Hal ini tidak akan bisa berjalan sempurna, jika dia belum mampu 
mengurus harta kekayaan. Berdasarkan ketentuan umum tersebut, para ahli Fiqih dan ahli undang-undang sepakat untuk menetapkan bahwa seseorang akan diminta pertanggungjawaban atas perbuatannya dan mempunyai kebebasan untuk menentukan hidupnya setelah cukup umur atau baligh. Mulainya masa usia baligh dapat berbeda-beda antara seseorang dengan orang lainnya. Hal ini bisa disebabkan karena perbedaan lingkungan, geografis, kebiasaan, genetika dan sebagainya.

Dilihat dari perspektif hukum, usia awal menikah diatur dalam Undang-Undang Perkawinan No. 1. Tahun 1974 sebagai berikut: (a). Pasal 6: ayat (1) Perkawinan harus didasarkan atas persetujuan kedua calon mempelai dan (2). Untuk melangsungkan perkawinan seorang yang belum mencapai umur 21 (dua puluh satu) tahun harus mendapat izin kedua orang tua. (B). Pasal 7: AYAT (1) Perkawinan hanya diizinkan jika pihak pria sudah mencapai umur 19 (sembilan belas) tahun dan pihak wanita sudah mencapai umur 16 (enam belas) tahun.

Terakhir apabila dilihat dari perspektif kesehatan maupun biologis, maka usia menikah ideal berkisar pada usia muda. Usia muda yang dimaksud yaitu ketika menginjak umur 20-an. Pada Usia ini adalah waktu yang tepat dari segi biologis untuk berbadan dua. Pada usia ini, tingkat kesuburan yang sangat tinggi, dan sel telur yang diproduksi pun sangat melimpah. Risiko memiliki bayi lahir cacat juga lebih sedikit karena kualitas sel telur yang diproduksi pada usia 20-an masih sangat baik. Kerentanan secara biologis dan reproduksi pada wanita semakin meningkat sejalan dengan bertambahnya usia, terutama pada usia diatas 35 tahun.

Jika dilihat dari ketiga perspektif diatas, artinya mahasiswa (dengan kisaran usia 1922 tahun) sudah diperbolehkan untuk melaksanakan pernikahan, bahkan ideal menurut perspektif biologis dan kesehatan. Walaupun pada faktanya, menikah pada saat sedang aktif proses belajar di kampus tidaklah mudah untuk dilaksanakan karena banyak hal yang mesti dilihat untuk dijadikan sebagai pertimbangan dan pengevaluasian, mulai dari masalah ekonomi atau pendapatan, tempat tinggal, manajemen waktu, rasa tanggung jawab (sebagai mahasiswa dan sebagai suami atau istri), dan lain-lain.
Perbandingan antara jumlah mahasiswa yang sudah menikah dibandingkan dengan yang belum menikah sangatlah kecil. Namun demikian, fenomena menikah muda di kalangan mahasiswa merupakan kejadian unik dan menarik jika di lihat dari sisi motivasi baik dari aspek religi, psikologi, sosial maupun akademiknya. Memang, bagi sebagian mahasiswa yang menikah muda mungkin bukan pilihan yang disebabkan mengikuti tren semata, namun lebih kepada anggapan bahwa pernikahan tersebut merupakan solusi atas masalah yang dihadapinya. Dari beberapa penelusuran dari peneliti, terdapat berbagai motivasi dan alasan yang menyertai pernikahan mahasiswa untuk menikah diantaranya karena alasan agama, ekonomi, sosial, dan budaya (Hakim, 2013)

Pernikahan usia muda cukup banyak diperhatikan oleh psikolog maupun pemerhati anak dan remaja di kota Medan khususnya mahasiswa dan mahasiswi di Universitas Negeri Medan.

\section{METODOLOGI PENELITIAN}

Penelitian ini dilaksanakan di Universitas Negeri Medan. Universitas Negeri Medan memiliki lebih dari 3000 mahasiswa yang diterima menjadi mahasiswa baru setiap tahunnya. Dari seluruh total mahasiswa pada 7 fakultas di Universitas Negeri Medan, diambil sebanyak 77 orang sampel (mahasiswa) dengan masing-masing 11 mahasiswa dari 7 fakultas, yaitu Fakultas Ilmu Pendidikan, Fakultas Ekonomi, Fakultas IImu Keolahragaan, Fakultas Matematika dan IImu Pengetahuan Alam, Fakultas IImu Sosial, Fakultas Teknik dan Fakultas Bahasa dan Seni.

Teknik pengumpulan data yang digunakan yaitu dengan menggunakan kuesioner. Teknik analisis data yang digunakan yaitu dengan menggunakan teknik analisis data deskriptif dengan pendekatan kualitatif.

\section{HASIL DAN PEMBAHASAN}

Umur perempuan menikah sesuai program adalah minimal 20 tahun. Batasan umur ini didasarkan atas pertimbangan umur reproduksi yang sehat bagi wanita. Namun demikian sosialisasi tentang hal ini belum merata diterima keluarga. Bila responden mahasiswa yang memberikan pendapat setuju atau sangat setuju terhadap pernyataam remaja perempuan menikah pada umur kurang dari 20 tahun, maka responden tidak mendukung program 
pemerintah dalam upaya pendewasaan usia kawin pertama.

Data yang diperoleh dari hasil penelitian melalui kuesioner adalah, pendapat terendah yaitu sangat setuju sebesar $5,19 \%$, dan setuju sebesar 10,39\%. Sedangkan mahasiswa yang tidak setuju dengan pernikahan dibawah 20 tahun sebesar $38,96 \%$ dan yang berpendapat sangat tidak setuju sebesar $10,4 \%$, sisanya sebesar $35,06 \%$ netral. Data hasil penelitian dapat dilihat pada tabel 1 dibawah ini.

Tabel 1. Pendapat Mahasiswa Universitas Negeri Medan Mengenai Umur Awal Pernikahan Remaja Perempuan Kurang dari 20 Tahun

\begin{tabular}{|c|c|c|c|c|c|c|}
\hline \multirow[b]{2}{*}{ Karakteristik } & \multicolumn{6}{|c|}{ Remaja Menikah Sebelum Usia 20 Tahun } \\
\hline & $\begin{array}{l}\text { Sangat } \\
\text { setuju } \\
\text { (1) }\end{array}$ & $\begin{array}{l}\text { Setuju } \\
(2)\end{array}$ & $\begin{array}{l}\text { Netral } \\
\text { (3) }\end{array}$ & $\begin{array}{l}\text { Tidak } \\
\text { setuju } \\
(4)\end{array}$ & $\begin{array}{l}\text { Sangat } \\
\text { tidak } \\
\text { setuju } \\
(5)\end{array}$ & Jumlah \\
\hline FMIPA & 2 & 1 & 5 & 1 & 2 & 11 \\
\hline FT & & 1 & 3 & 6 & 1 & 11 \\
\hline FBS & & 2 & 2 & 7 & & 11 \\
\hline FIS & & 1 & 3 & 3 & 4 & 11 \\
\hline FIK & 1 & 1 & 5 & 4 & & 11 \\
\hline FIP & & & 7 & 4 & & 11 \\
\hline FE & 1 & 2 & 2 & 5 & 1 & 11 \\
\hline Total & 4 & 8 & 27 & 30 & 8 & 77 \\
\hline Persentase & $5,19 \%$ & $10,39 \%$ & $35,06 \%$ & $38,96 \%$ & $10,40 \%$ & $100 \%$ \\
\hline
\end{tabular}

\section{Diagram Pendapat Mahasiswa UNIMED Mengenai Umur Awal Pernikahan Remaja Perempuan Kurang dari 20 Tahun}

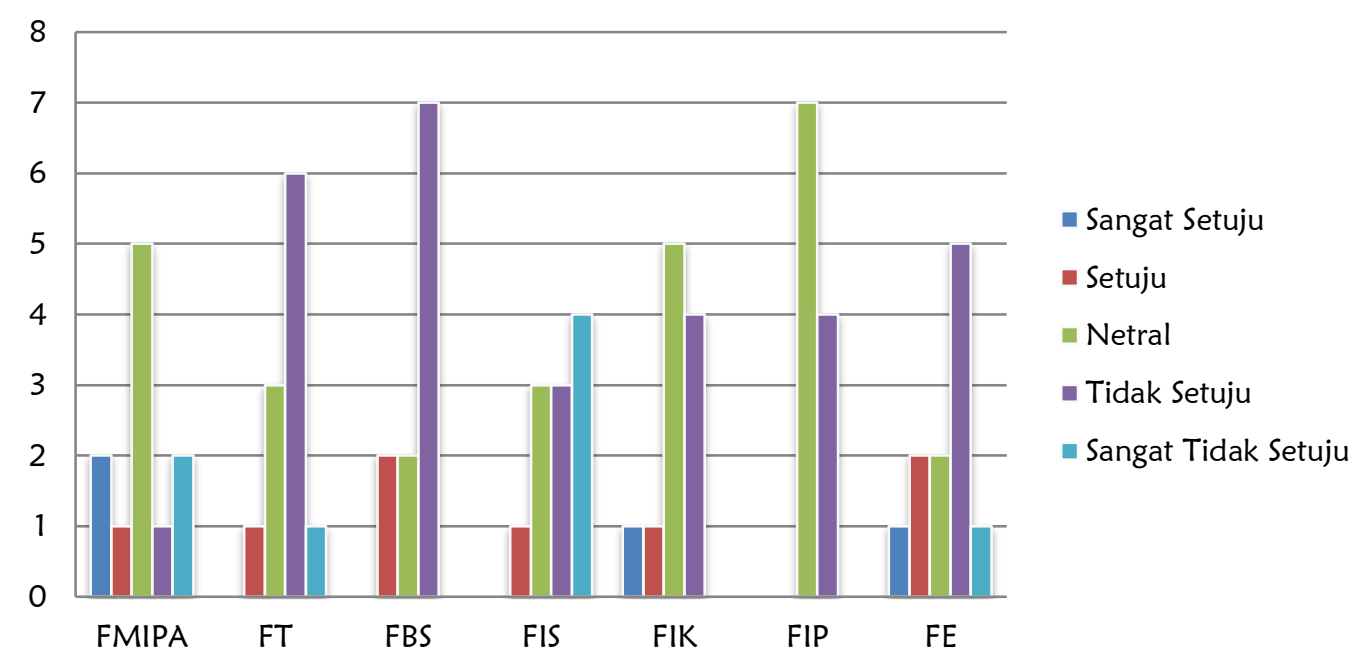

Gambar 1. Diagram Pendapat mahasiswa UNIMED Mengenai Umur Awal Pernikahan Remaja Perempuan Kurang dari 20 tahun 
Perkawinan hanya dapat dilakukan oleh seorang pria dan seorang wanita jika telah mencapai usia tertentu. Jika pria dan atau wanita tersebut belum mencapai umur sesuai yang telah diatur dalam peraturan perundang-undangan, maka jika akan melakukan perkawinan harus mendapatkan izin terlebih dahulu. Berdasarkan peraturan perundang-undangan, suatu perkawinan hanya boleh dilakukan jika pria telah berumur 19 tahun dan wanita telah berumur 16 tahun. Dan jika ada orang yang akan melakukan perkawinan tetapi belum mencapai umur 21 tahun, maka ia harus mendapat izin dari orang tuanya. Maksud dan tujuan undang-undang memberikan batasan umur bagi pria dan wanita yang akan melangsungkan perkawinan adalah untuk terciptanya kemaslahatan keluarga dan rumah tangga (Hardani, 2015).
Namun sering terjadi di masyarakat suatu perkawinan itu dilakukan oleh orangorang yang umurnya belum mencapai 19 tahun bagi pria dan belum mencapai 16 tahun bagi wanita. Jika ini terjadi, maka undang-undang telah mengatur mengenai pelaksanaannya. Seorang pria dan wanita yang akan melangsungkan perkawinan tetapi umurnya belum mencapai 19 tahun dan 16 tahun, maka dapat mengajukan permohonan dispensasi kawin kepada Pengadilan setempat yang diajukan oleh kedua orang tua pihak pria maupun wanita. Dan produk dari permohonan dispensasi kawin nantinya adalah berupa penetapan. Dibawah ini merupakan diagram pendapat mahasiswa Universitas Negeri Medan (UNIMED) mengenai umur awal pernikahan remaja perempuan kurang dari 20 tahun.

\section{Persentase Pendapat Mahasiswa UNIMED Mengenai Umur Awal Pernikahan Remaja Perempuan Kurang dari 20 Tahun}

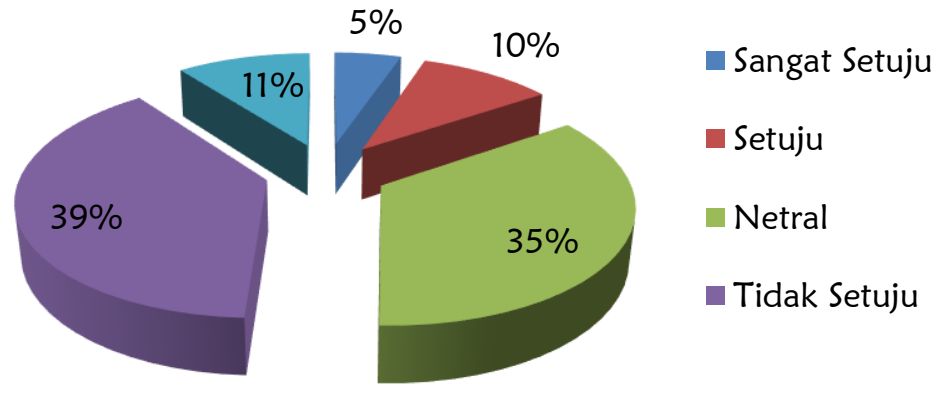

Gambar 2. Persentase Pendapat Mahasiswa UNIMED Mengenai Umur Awal Pernikahan Remaja Perempuan Kurang Dari 20 Tahun

Dari diagram di atas, dapat kita ketahui bahwa mahasiswa yang berpendapat sangat setuju mengenai umur awal pernikahan remaja perempuan kurang dari 20 tahun sebanyak 5\%, berpendapat setuju $10 \%$, berpendapat netral 35\%, berpendapat tidak setuju 39\% dan berpendapat sangat tidak setuju sebesar $11 \%$. Dengan kata lain pendapat mahasiswa Universitas Negeri Medan mengenai umur awal pernikahan remaja perempuan kurang dari 20 tahun sebagian besar tidak setuju yaitu sebanyak $39 \%$ dan netral sebanyak 35\%.

Umur yang ideal untuk menikah yaitu berkisar antara umur 21 tahun bagi perempuan dan 25 tahun bagi laki-laki. Hal ini dikarenakan sesuai dengan UndangUndang Perlindungan Anak, usia kurang dari 18 tahun masih tergolong anak-anak sehingga belum bisa untuk melakukan pernikahan (Hakim, 2016).

Berdasarkan kesehatan, umur yang ideal dan matang secara biologis dan psikologis adalah 20-25 tahun bagi wanita dan umur 25-30 tahun bagi pria. usia tersebutlah yang dianggap paling baik untuk melakukan pernikahan berdasarkan kesehatan karena pada usia tersebut baik pria maupun wanita sudah matang dan bisa berpikir dewasa secara rata-rata.

Rekomendasi ini ditujukan demi untuk kebaikan masyarakat atau pasangan yang ingin menikah, agar ketika pasangan tersebut menikah mereka sudah memiliki kesiapan yang matang dan dapat mengarungi rumah tangganya dengan baik sehingga terciptanya keluarga yang harmonis dan langgeng. Untuk membangun 
suatu keluarga yang harmonis dan langgeng tidaklah mudah, karena memerlukan sikap kedewasaan yang tinggi seta mampu menghadapi berbagai guncangan dan gangguan yang muncul baik itu dari segi ekonomi, masalah internal maupun masalah eksternal.

\section{KESIMPULAN}

Berdasarkan hasil penelitian dan pembahasan, maka dapat ditarik kesimpulan sebagai berikut:

1. Mahasiswa yang berpendapat sangat setuju mengenai umur awal pernikahan remaja perempuan kurang dari 20 tahun sebanyak 5\%, berpendapat setuju 10\%, berpendapat netral 35\%, berpendapat tidak setuju $39 \%$ dan berpendapat sangat tidak setuju sebesar $11 \%$. Dengan kata lain pendapat mahasiswa Universitas Negeri Medan mengenai umur awal pernikahan remaja perempuan kurang dari 20 tahun sebagian besar tidak setuju yaitu sebanyak 39\% dan netral sebanyak 35\%.

2. Umur yang ideal untuk menikah yaitu berkisar antara umur 21 tahun bagi perempuan dan 25 tahun bagi lakilaki. Berdasarkan kesehatan, umur yang ideal dan matang secara biologis dan psikologis adalah 20-25 tahun bagi wanita dan umur 25-30 tahun bagi pria. usia tersebutlah yang dianggap paling baik untuk melakukan pernikahan berdasarkan kesehatan karena pada usia tersebut baik pria maupun wanita sudah matang dan bisa berpikir dewasa secara rata-rata.

\section{SARAN}

Berdasarkan hasil penelitian dan Pembahasan pada bab sebelumnya, maka dapat dikemukakan saran yaitu pendapat Mahasiswa Universitas Negeri medan mengenai umur awal pernikahan remaja putri kurang dari 20 tahun yaitu sebagian besar tidak setuju dan sebagian besar lagi yaitu netral. Oleh karena itu perlu adanya sosialisasi tentang dampak pernikahan usia dini di Universitas Negeri Medan untuk tetap menjaga mereka dalam mempertahankan pendapatnya tentang tidak baiknya melakukan pernikahan pada usia dibawah 20 tahun.

\section{UCAPAN TERIMA KASIH}

Tim peneliti mengucapkan banyak terima kasih kepada responden-responden kami yang telah bersedia membantu dalam melakukan penelitian. Dan tidak lupa pula kami ucapkan kepada dosen pengampu mata kuliah Geografi Kependudukan dan Demografi Jurusan Pendidikan Geografi Universitas Negeri Medan.

\section{DAFTAR PUSTAKA}

Atkinson, R.L., Atkinson, R.C., Hilgard, E.R. (1999). Pengantar Psikologi Jilid II. Jakarta: Erlangga

Halls, G.S \& Lindsey, E. 1993. Teori-Teori Holistik. Alih Bahasa: Supratiknya, A. Yogyakarta : Kanisius.

Rafidah, K., Azizah, A., Norzaidi,M.Daud., Chong, S.Choy., Salwani, M.Intan., \& Noraini, Ibrahim.(2009). Stress and Academic Performance: Empirical Evidence From University Students. Academic of Educational Leadership Journal, Vol. 13, No.1.

Nurwati N. (2003). Pusat Penelitian Kependudukan UNPAD Perkawinan Dan Perceraian Pada Masyarakat Jawa Barat. Jurnal Kependudukan Padjadjaran, Bandung; Halaman 5967

Hardani, Sofia (2015). Analisis Tentang Batas Umur Untuk Melangsungkan Perkawinan Menurut Perundangundangan Di Indonesia. Jurnal Pemikiran Islam. Hal. 126-139.Volume 40 No.2.Juli-Agustus 2015.UIN Suska Riau

Hakim, Luqman Faisal.(2013). Batas Minimal Usia Kawin Ideal Bagi Pria dan Wanita; Studi atas 58 Penetapan Dispensasi Kawin di Pengadilan Agama Yogyakarta Tahun 2011.Jurnal Supremasi Hukum. Hal. 217244.Volume 2 No.1. Juni 2013.Universitas Islam Negeri Sunan Kalijaga Yogyakarta.

Fatmawati, D. 2009. Hubungan beberapa Faktor pada Wanita dengan Kejadian Pernikahan Usia Dini (Studi di Kecamatan Sragi Kabupaten Pekalongan Tahun 2009). Tidak diterbitkan.

Hakim, Lukman Nur. (2016). Rekonstruksi Batas Minimal Usia Nikah Berdasarkan Pendapat Para Ahli dan Putusan Mahkamah Konstitusi No.30-74/PUUXII/2014.Skripsi Universitas Islam 
Negeri Maulana Malik Ibrahim Malang. Malang. $235 \mathrm{hlm}$

RI (Republik Indonesia). Undang-Undang No. 1 Tahun 1974 pasal 6 ayat (1) dan (2).

RI (Republik Indonesia). Undang-Undang No. 1 Tahun 1974 pasal 7 ayat (1).
RI (Republik Indonesia). Undang-Undang No. 35 tahun 2014 tentang Perlindungan Anak. 